University of Nebraska - Lincoln

DigitalCommons@University of Nebraska - Lincoln

Faculty Publications: Department of Teaching, Department of Teaching, Learning and Teacher Learning and Teacher Education

Education

February 1999

\title{
Anglo (Mis)Understandings of Latino Newcomers: A North Georgia Case Study
}

\author{
Edmund T. Hamann \\ University of Nebraska - Lincoln, ehamann2@unl.edu
}

Follow this and additional works at: https://digitalcommons.unl.edu/teachlearnfacpub

Part of the Teacher Education and Professional Development Commons

Hamann, Edmund T., "Anglo (Mis)Understandings of Latino Newcomers: A North Georgia Case Study" (1999). Faculty Publications: Department of Teaching, Learning and Teacher Education. 72. https://digitalcommons.unl.edu/teachlearnfacpub/72

This Article is brought to you for free and open access by the Department of Teaching, Learning and Teacher Education at DigitalCommons@University of Nebraska - Lincoln. It has been accepted for inclusion in Faculty Publications: Department of Teaching, Learning and Teacher Education by an authorized administrator of DigitalCommons@University of Nebraska - Lincoln. 


\title{
Anglo (Mis)Understandings of Latino Newcomers: A North Georgia Case Study
}

\author{
Edmund T. Hamann
}

This paper examines how Anglos in a small north Georgia city imagined, or conceptualized, Hispanics during the late 1990s as thousands of Spanishspeaking immigrant newcomers transformed the community's demography. Based on two years of ethnographic research, the paper outlines the local play of several macro-social dynamics, such as businesses' externalization of indirect costs, the ethnic segmentation of the work force, the use of sojourner labor, and the role of mediating institutions. The paper uses these dynamics to explain the emergence and sustenance of what Suárez-Orozco (1998) calls the "pro-immigration" and "anti-immigration scripts" and illustrates how these can be used to explain local circumstances. Ultimately, the paper illustrates how Anglos' creation of simplified conceptualizations of the new Latino "other" limited the transformative potential of a novel binational partnership that brought together the local schools, local business leaders, and a private university in Mexico.

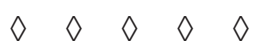

In 1960 the world was a different place. Coming into town on Highway 41 from the north, the initial greeting sat rooted into a piece of ground just off the railroad tracks that nestled behind Crown Mills. A sign of somewhat large proportions titled [Conasauga] the Carpet Capital of the World and down below, near the bottom, in black lettering on white, was the local population. It was no staggering figure, having learned of the droves of humanity in such cities as Chicago and New York, but it was a comfortable total.

The bulk of business took place downtown. Shops and banks thrived. Ten cent stores were high on the list. The U.S. Cafe, right there on Hamilton in the center of this tiny universe, and Oakwood were ballyhooed for miles. 
Glenwood, past the fairgrounds and Legion Field, was less populated. Walnut Avenue slept in residential bliss. The interstate highway had not yet cut a swath through the north end of Georgia, and the mail was still, for the most part, delivered on foot. ... Driving the streets, it was difficult to see a passing face that a name could not be placed beneath. Needless to say, the face of this little town has changed, both in detail and expression. Now, even the language is in question.

With the growth of the carpet industry and the lack of adequate labor on several different levels, the need for a work force escalated. While many work arenas suffered financially, even to the point of extinction, [Conasauga] continued to offer a valid job list.

It is a secret to no one that this town is now approximately 25 percent Hispanic as the border of this country offers continued hope for those seeking gainful employment and a new, better life. But change has its price.

-Larry Green (sports columnist)

The Daily Citizen News-May 1996

\section{Introduction}

This paper examines the imagining, or conceptualizing, of Hispanic immigrant newcomers by local Anglos in a small city in Appalachian northwestern Georgia. ${ }^{1}$ In general, it is a paper about the ideological environment encountered by and constructed about Hispanic immigrants; more particularly, it is about the imaginings of these Anglos in relation to a specific binational partnership (referred to here as the "Binational Partnership") that was initiated in the community in 1996 as the primary formal public response to this community's rapidly changing demography.

Anglo conceptualizations of Hispanics in this city were the product of existing assumptions about self, place, community, and group identity and of superficial encounters with Hispanics in the workplace, at school, and in a few other public settings. Anglo conceptualizations also were the product of their vicarious experiences with Hispanics through representations in the media and in the daily talk of their fellow Anglo (and to a lesser extent African-American) community members. These vicarious experiences included Anglos noting that local public school enrollment 
had shifted from more than $90 \%$ white in 1989 to over $41 \%$ Hispanic by 1998. This change was partially based on limited white flight, but it reflected more the enrollment of nearly two thousand Hispanic newcomers in the schools and the arrival of 15,000 or more Hispanics into the larger community.

Much of the imagining of the Hispanic $o t h e r^{2}$ in this community was shaped by the business and civic elite who were responsible for the hiring practices at local poultry and carpet facilities that brought thousands of Hispanic workers and their families to the city of Conasauga and to surrounding Dameron County. ${ }^{3}$ This same elite instigated a novel binational collaboration which formally partnered the Conasauga Public Schools with researchers at a private university in Mexico. The Binational Partnership became a template for Anglos' thinking about the school and community accommodations required by the new demography. ${ }^{4}$

The Partnership was erected quickly. First considered in the summer of 1996, by the summer of 1997 it had four official components and over a million dollars of funding from several sources. ${ }^{5}$ The Partnership promised bilingual adjustments of the schools' curricula, supplementation of the local teaching force with instructors from Mexico, revision of teacher training (including a comprehensive professional institute in which Conasauga teachers were sent to Mexico for a month), and a combined Hispanic community study and leadership development initiative. Although this final component was approved by the Conasauga Anglos spearheading the Partnership, its enactment did not much involve them or other local Anglos. Thus, it was not a significant contributor, at least during my study period, to local Anglos' conceptualizations of Hispanics, although it did change many Hispanics' sense of community membership. The influence of the other three components on Anglo thinking about Hispanics varied, and it remained intertwined with and, at times, overshadowed by Anglos' meaning-making related to workplace changes, economic adjustment, representations of Hispanics in the popular media, and other macro-dynamics that were part of Conasauga's ongoing, large-scale demographic reconfiguration.

In this paper, after describing the transnational social and labor dynamics that were reconfiguring Conasauga, I introduce two main frameworks for this analysis-Marcelo Suárez-Orozco's (1998) delineation of seemingly opposite but necessarily partnered "pro-immigration" and 
"anti-immigration scripts" 6 and Jane Gibson's (1996) analysis of how the social construction of whiteness by and in regard to low-income whites is intertwined with the reproduction of social inequality, including the inequality that disadvantages low-income whites. Suárez-Orozco's "anti immigration script" refers to the social construction of immigrants as job-stealing, illegal, lazy, social service-abusing, suspicious, and criminal. In contrast, the "pro-immigration script" constructs immigrants as hardworking, familial, loyal, religious, thrifty, and otherwise virtuous. Espousers of the pro-immigration script often favorably compare immigrants to their non-immigrant co-workers and neighbors who, it is often implied, lack the virtues noted above. Importantly, neither immigration script actually includes voices of immigrants, and both scripts are inflexible. Both scripts are used for formal and informal debates by natives about how immigrants should be treated and what social station they should be offered by the host society. Necessarily tied to such debates is the social construction of the class-related meanings of being native and being white, which is where Gibson's analysis fits in.

The bulk of this paper focuses on how the host community in Conasauga understood the issues and challenges it faced as a result of a rapid influx of Hispanic newcomers. Suárez-Orozco's and Gibson's frameworks are used to suggest that despite the novelty and promise of the Binational Partnership - the main local substantive response to the new demography - the power of existing scripts and expectations meant that much of the original transformative promise was lost (or deferred) as the effort to popularize and promote the Binational Partnership compelled local Anglos to use their existing cultural frameworks to try to understand the new effort. The rationale for the complex, four component Partnership as a means of valuing diversity, promoting intercultural understanding, and creating a multicultural community vision was reduced in public discourse to being merely a creative attempt to teach newcomers English and to help them assimilate. Moreover, it was unclear whether the assimilation purportedly offered in the Partnership's redefined public mission was anything more than what Spener (1988) has called "assimilation at the bottom."

Before turning to the analysis of the dynamics that were shaping Conasauga at the end of the 20th century, I offer three final caveats. First, the use of the term "Hispanic" in this study reflects local practice. At the 
time of my study, well-intentioned Anglos had been told by local Hispanics that "Hispanic" was a preferable term to "Latino," though the latter term was also used, as was the nation-oriented term "Mexican." Second, the rendering that follows consciously uses the past tense. Even though the changes in demography and the Binational Partnership were both ongoing concerns at the time of my writing, I, like Delgado-Gaitan (1990), have consciously avoided using the ethnographic present because I do not want to imply that conceptualizations of Hispanics by Anglos in Conasauga were static. They were not. Third, Sarason (1990) emphasizes that no one needs to act maliciously for reform movements (like the Binational Partnership) to become unwittingly reiterations of the status quo. Though their behaviors and understandings were not necessarily transformative or even egalitarian, none of the people described below can be dismissed as simply malicious. The tale rendered in this paper does not require a "bad guy" to explain why results were less progressive than the original action plan of the Partnership had proposed.

\section{Hispanics and the Labor Market-The Backdrop for Anglo Conceptualizing}

At a January 1997 dinner party that was organized to celebrate the first visit of the Mexican university scholars to Conasauga, the attorney who instigated the Binational Partnership declared in an after-dinner toast that Conasauga had become a "border city" and had a responsibility to act inclusively in regard to this new status. From his perspective there were enough Mexicans in Conasauga at that point, persons whose reference point and identity were intertwined with Mexico and not just the United States, that characterizing Conasauga's population as American was an incomplete gesture. ${ }^{7}$ The comment impressed the visitors from the Mexican university as particularly insightful, but, from their perspective, it was actually intended not for them but instead as a challenge to the thinking of the Anglo Conasaugans assembled in the room. Why the lead proponent of the Binational Partnership thought that such a challenge might have been necessary and, more directly, what dynamics his comment referred to are central topics of this segment.

This segment explores the transnational economic dynamics that were bringing Hispanics to Conasauga, the industrial strategies that 
drove and shaped these dynamics, and the ideological constructions that were intertwined with both the corporate strategy-making and the acceptance of these strategies by community members. The exploration builds from several theoretical constructs, among them the role of mediating institutions (Lamphere 1992), the idea of externalizing indirect costs (Hackenberg 1995) the creation and use of segmented labor markets (Griffith 1995), the role of sojourner labor (Hackenberg 1995; Smith and Guarnizo 1998), the idea of imagining oneself as part (or not part) of a community (Chavez 1994), and the maturation of migration streams (Tienda 1989).

Lamphere (1992) noted that "mediating institutions" are key sites at which relations between newcomers and established residents are shaped. Goode, Schneider, and Blanc (1992) identified school systems as prominent mediating institutions. Workplaces and the popular media are also examples of mediating institutions. A main function of mediating institutions is to channel larger political and economic forces into settings/ formats that impact the lives of individuals. Ideologies regarding assimilation, status hierarchies, cultural identity, and ethnic boundaries are all contested, negotiated, and internalized through mediating institutions. Negotiating the business community's externalization of indirect labor costs is just a first example of how a macro-social trend became manifest in Conasauga at the individual level, as schools, churches, and other social service providers were compelled to hire interpreters, to provide emergency assistance, and otherwise to reconfigure their deployment of resources.

Two local dynamics triggered the arrival of newcomers into Conasauga and instigated the mediating role of a number of institutions: the corporate practice of externalizing indirect costs and the related practice of using and reproducing a segmented labor market. In discussing many ways that changes in the meat-packing industry are affecting small town demographics and articulating new links between these towns and distant locales, Hackenberg (1995:238) noted that one challenge for meat-packing businesses has been to figure out ways to externalize their indirect labor costs, i.e., the costs of housing, health care, language instruction, skills training, and other human services. From the standpoint of corporate profitability, companies that externalize costs gain from others' carrying their indirect costs (Griffith 1993). 
While Conasauga was host to only one meat-packing plant (a poultry processing facility), the employment strategies of the carpet companies, the main local employers, in many ways matched those of the meat-packing industry. As an example of externalizing indirect costs, a prominent Protestant clergyman whose parish included some of the leading carpet executives in Conasauga once complained to me that his Hispanic bilingual colleague routinely received late night calls to come to the hospital to interpret because of an injury at one of the mills. He clarified that the carpet companies should have had bilingual human relations managers on their employment rolls to assist with such incidents.

Susceptible to charges that they were externalizing costs, the carpet and poultry companies in Conasauga could and did claim that, as producers in mature industries, cutting costs was the only way to ensure their continued viability, at least in their existing U.S. locations. Mencken (1996) and Gaventa (1990) have noted Appalachia's disproportionate reliance on manufacturing and the region's resultant disproportionate exposure to the effects of the globalizing economy. Competing with manufacturers in lower-wage countries, Conasauga business leaders had an incentive to try to externalize as many indirect costs as possible, and they could and did claim a rationale other than greed for this practice. That the carpet industry was achieving record earnings in the 1990s did not interfere with the espoused story lines of economic vulnerability nor with carpet executives' claims that their corporate goodwill was sufficiently manifest in their decision to continue manufacturing locally, to be philanthropically active, and to pay taxes.

In 1997, Conasauga's local newspaper acknowledged that there was a public complaint about externalization of costs in Conasauga:

[The] former superintendent of Conasauga Public Schools said more than once to our reporters that business and industry here must get more involved with solving community problems related to the rapid growth of the Hispanic community. ... After all, our Hispanic neighbors are here because local businesses gave them jobs. ... Business leaders here must accept some responsibility beyond handing out a regular paycheck. (The Daily Citizen News 1997a:4A) 
But the newspaper brought up this dynamic to praise local businesses for organizing the new Binational Partnership (ignoring that much of the business community showed little immediate interest in it) and, indirectly, to counter the former Superintendent's claim. According to the newspaper's editorial board, the Binational Partnership's existence refuted the criticism that businesses were not meeting their community responsibilities.

In contrast to many Appalachian communities (Gaventa 1990) and the immigration-impacted Georgia community studied by Griffith (1995), most of the manufacturing in Conasauga was owned and controlled by Conasauga residents, not outside corporations. Thus, while externalizing indirect costs helped company bottom lines, the executives pursuing such strategies had, as community members, to live with the consequences of such strategies. This did not stop the practice of externalizing indirect costs, but this reality, combined with a century-long tradition of personalized philanthropic civic involvement by the local elite (Flamming 1992), did compel local leaders to act in ways that seemed socially accountable. It was from this contradiction between executives' habits of externalizing indirect costs and their desire and self-concept to appear as involved citizens that the impetus for the Binational Partnership was generated.

Related to the process of externalizing indirect costs, carpet and poultry producers in Conasauga also sought to reduce costs by creating, or at least benefiting from, "segmented labor markets"8 Griffith 1995: 148), in which internalized ideas regarding job-status hierarchies and corresponding wage differentials are not questioned by workers. For segmented labor markets to remain viable, there needs to be palatable ideological rationalizations for socioeconomic differentiations and for deflections of challenges to the unequal social structure. Differences in race, ethnicity, language, age, gender, and school experience often become grounds for such differentiation. As local instigators of a widespread process that Griffith (1995: 129) calls the "Latinization of low-wage labor" and that Hackenberg (1995:261) refers to as the "Latin-Americanization of the secondary labor sector," Conasauga's carpet and poultry producers were centrally involved in the recruitment of Hispanic labor, particularly Spanish-speaking, newcomer labor, to lower status jobs. ${ }^{9}$ 
At many of these companies, certain hazardous and/or low prestige jobs became "Mexican-typed jobs." Within segmented labor markets, the insertion of "Mexican-typed jobs" (Tienda and Fielding 1987; Tienda 1989) is relatively easy. Certain jobs, typically those of lowest status and/ or the most difficult or dangerous circumstances, are so frequently occupied by Mexicans (or Mexican-Americans) that they become associated with that ethnic identity. According to the tacit codes of the workplace, such employment niches are for Mexicans. In turn, because of their relatively advantaged access to these job niches, Mexicans seek to recruit friends and family members for job openings, while the actions of nonMexicans in other niches protects the higher status of those other positions. This segmentation works against the creation of cross-niche and cross-ethnic solidarity and tacitly limits the collective power that workers can wield to improve wages, benefits, or other job conditions. Moreover, since social and work networks often overlay each other, this segmentation tacitly reproduces a sense of ethnic hierarchy that is carried outside the workplace into community social relations.

The regional context of the dynamics that built a demand for Mexican labor in Conasauga included the increase in Southeastern economic activity in recent decades that was based on low costs and comparatively lax environmental standards that attracted industries, but also generated new wealth and demands for higher wages, better schools, and so on. In this context, the previously available native, low-wage labor supply began to demand both higher wages and to diminish (Griffith 1995). For companies, these changes increased operating costs and reduced profits, hence a demand for a new supply of surplus, tolerant labor, in this case one from Latin America. To reduce or maintain low labor costs, specific Conasauga companies have not always needed to attract large numbers of newcomer laborers, although many have. The prospect of an alternative labor supply has often been sufficient to undermine demand for higher wages among existing employees. ${ }^{10}$

Though the following label applies to only a portion of the Hispanic newcomer labor force in Conasauga, the poultry processing facility and many carpet producers have hired workers whom Hackenberg (1995:248) categorizes as "sojourner laborers," i.e., those integrated into a system that Smith and Guarnizo (1998) label "transnationalism from below." As the name implies, such laborers are not particularly rooted in the community 
where they work. They are neither seen by the larger community as part of it, nor do they imagine themselves as community members. Chavez (1994) has found that the residential transiency of immigrant Mexican and Central American laborers was four to five times higher if those laborers did not imagine themselves as part of the community where they lived. While attachment to community is felt individually, it is worth remembering that such feelings are a product of social history and interaction.

Sojourner laborers may not feel rooted in the communities where they work because their employers have favored high turnover rates to avoid having to bear health care costs and other benefits nominally on offer after workers complete an introductory probationary period. Yet, if they call someplace else home, e.g., a locale in Mexico, sojourner laborers often do not readily have a means to stay in that place because of economic dislocation processes operative there ${ }^{11}$ (Portes and Bach 1985:112-115). Circular migrants, such as those involved in field agricultural labor, those alluded to by Massey, Alarcon, Durand and Gonzalez (1987), and members of "transnational communities"(Guerra 1998) fit into the sojourner category. According to Guerra's model, situating Mexican newcomers in a single geographic location is incomplete, as such newcomers physically and ideationally embrace communities both in U.S. and Mexican locales.

Hiring and firing sojourner laborers works as a corporate strategy as long as the company does not have to make a significant investment in employee training and as long as a willing supply of new labor persists. To facilitate the latter, major meat-packers will often pay recruitment bonuses to individuals who recruit new workers. I never confirmed whether Conasauga's carpet manufacturers, the ancillary carpet industry support companies, or the poultry plant paid recruitment bonuses to employees, despite rumors that such was the case. Because sojourner laborers often represent a particular racial/ethnic identity, corporate use of sojourner labor can also function as a way of reproducing labor segmentation and ethnic-typing of job categories.

From a community perspective, sojourner laborers and their families are often viewed, not surprisingly, as temporary and due only minimal accommodation. This appeared to be the case in Conasauga as an early and consistent public relations endeavor of the Binational Partnership proponents was to affirm that Conasauga's Hispanic population was settling there permanently and hence deserved accommodation. While 
much permanent and semi-permanent Hispanic settlement was occurring, the Partnership proponents' discourse left unchallenged the assumption that sojourner workers and their families were not due accommodation. Moreover, there was an unacknowledged contradiction between some Conasauga Anglo corporate leaders' discourse and their corporate practice, as the willing use of Hispanic sojourner labor was not reconciled with leaders' simultaneous claims that the Hispanic work force was a permanent presence and for that reason deserving support.

The Partnership's proponents' and others' discourse that "Hispanics are here permanently" allowed many Anglos to construct the task of schooling along strictly assimilationist terms (i.e., expecting unilateral change on the part of the newcomers). ${ }^{12}$ Such a construction did not account for the prospect that many newcomer children (and other Conasauga children too) needed to learn to negotiate multiple linguistic, cultural, and geographic environments. According to the earlier construction, Anglos could view Hispanics as sojourners and thus not care much about them, except as a source of needed labor. According to the second construction, Anglos could view Hispanics as permanent and therefore needing (and deserving) simplistic and straightforward assimilation.

Two more points are important before the following detailed discussion of Marcelo Suárez-Orozco's (1998) pro-immigration and anti-immigration scripts and Gibson's (1996) analysis of the social construction of whiteness. First, as Tienda (1989) would have predicted, Conasauga's migrant streams were maturing, with exploding Hispanic school district enrollments as one consequence. Massey et al. (1987) point out that migration links become "self-sustaining social processes." From the late 1980s through the end of my study period, an increasing proportion of Hispanics coming into Conasauga were children and spouses of workers. As this dynamic became more significant, the local Hispanic presence became more visible. The industries that were externalizing their indirect costs became economically more costly to the community (though some of the costs were born by the newcomers who paid taxes and one could argue that family reunification represented added social value not cost).

Second, a series of feedback loops were created in the multiplicity of sites accommodating Hispanic newcomers; it was characterized by a multi-directional dynamic in which conceptualizations of Hispanics at school, at work, in the media, and in the popular imagination inter- 
acted. This more complex contribution to Anglo imagining of Hispanics replaced a previous "out of sight, out of mind" stance. However, in the next section, I suggest that various inputs used by Anglos did not mean, or at least did not quickly mean, that the imagining of Hispanics became correspondingly more complex and nuanced.

\section{The "Pro-Immigration" and "Anti-immigration Scripts"}

The above thumb-nail sketch puts in context some of the forces driving Conasauga's demographic changes and how these changes explained the emergence of the "pro-immigration script," the "anti immigration script" (Suárez-Orozco 1998) and a third phenomenon-"dislocation." Dislocation refers to the cultural malaise and anxiety that seems dominant at the end of the millennium in the United States and Western Europe. This anxiety is related to the instability of post-modern employment and to a simultaneous sense of lost community and lost shared values. To quote political theorist Michael Sandel (1996:1):

Two concerns lie at the heart of [U.S.] democracy's discontent. One is the fear that individually and collectively, we are losing control of the forces that govern our lives. The other is the sense that, from family to neighborhood to nation, the moral fabric of the community is unraveling around us. These two fears-for the loss of self-government and the erosion of community-together define the anxiety of the age.

Sandel also noted that the dominant political discourse was failing to relieve this anxiety, sometimes even cynically fanning it instead. These observations were seconded by Spindler and Spindler (1998). The nostalgic newspaper article (Green 1996) quoted at the start of this paper reflects this sense of loss and dislocation. Conasauga was no longer what it had been.

Both pro-immigration and anti-immigration scripts emerge from this sense of dislocation. The pro-immigration script derives much of its appeal from its nostalgic reiteration of the important domestic assimilationist myth that America is a land of opportunity-a land where hard work, even in trying circumstances, can lead to success-and thus, that Amer- 
ica is essentially fair. The pro-immigration script casts immigrants as familial, hard-working, religious, self-sacrificing, and loyal. In a time of worker anxiety and dislocation, such a familiar script is comforting. Immigrants offer the prospect of validating and rejuvenating America, but not, according to the script, of changing it.

Given the appeal of this script as myth, those who espouse it do not easily tolerate deviations from it. Both newcomers' resistance to forgetting a first language and characterizing employment conditions as less than fair violate the script and thus bring enmity to any immigrants who voice such complaints. The pro-immigration script may seem pro-immigrant, but it actually offers only a confining range of possible immigrant actions and little support for immigrants who contest what Spener (1988) calls the "ambiguous social contract" actually available in this socially stratified society. According to Spener:

The United States offers immigrants an ambiguous social contract. It reads, more or less, as follows: "In order to participate in a non-marginal way in the U.S. economy, you must become an American by giving up your loyalty to your home country and language, and you must learn the language of the American elite. In order to become an American, you must meet certain standards. This country is in the process of raising its standards because, unfortunately, there are already too many Americans. If you aren't allowed to become an American, there's still plenty of room for you in this country—at the bottom." (1988:145-146)

This purported U.S. social contract both matches and differs from what ethnic minority newcomers encounter in other countries. For example, in Germany Turks and other foreigners have been steered to the bottom of the social order too, but German progressives have protested this socioeconomic marginalization not by endorsing assimilation, but rather by promoting a plural, multicultural, tolerant vision of Germany (Macias 1996:244-245). Van Zenten (1997) has found that the so-called "Republican model" in France seems to support the cultural assimilation of immigrants but is less effective in promoting social and economic assimilation. 
Although the pro-immigration script's nostalgic appeal is broad, as is its gloss of inclusiveness, it is most comfortably embraced by those who gain directly from the presence of newcomer laborers. If the employment hierarchy can be equated to a pyramid, a proposition supported by segmented labor market theory (Griffith 1995), anyone in a position above those that are occupied by newcomer laborers benefits from the expansion of the employment base below them. This means immigration is often eyed as a good thing by most people in management, as well as those who share their class-level, like spouses, doctors, and lawyers. On repeated occasions, the carpet CEO who first facilitated Conasauga's partnering with the Mexican university emphasized that Conasauga's growing Hispanic presence was "an opportunity, not a problem."

In contrast, the "anti-immigration script" views the same change in community and workplace demography as threat rather than reassurance. Immigrants become illegal aliens, welfare cheats, criminals, and job stealers. The contradiction between alleged government dependency and stealing jobs is left unexplored. As Suarez-Orozco summarizes:

Anti-immigrant sentiment-including the jealous rage that "illegals are getting benefits instead of citizens like my friend"-is intertwined with an unsettling sense of panic in witnessing the metamorphosis of "home" into a world dominated by sinister aliens (1998:296-297).

Suárez-Orozco's anti-immigration script closely matched the virulently anti-immigrant content of the 1995 letters-to-the-editor that led Conasauga's daily newspaper to declare a temporary moratorium on publishing letters about immigration and Hispanics. The script also describes the arguments of the protesters who demonstrated in April 1997 outside a City Council meeting at which a $\$ 750,000$ municipal allocation for the Binational Partnership was being approved. Both of these scenarios are discussed further in the next segment.

Because the two scripts vehemently contradict each other, even as both ignore the actual voices of newcomers, those who espouse the different scripts tend to talk past each other, often heatedly, over a wide gulf. This miscommunication leaves the anxiety untouched, but dehumanizes 
the espousers of the opposite view such that their viewpoint and rationale can be readily dismissed. Because the pro-immigration script is typically used by the more powerful while the anti-immigration script is typically uttered by the less powerful, the powerful's rejection of the anti-immigrant script and its espousers becomes conflated with the play of hegemonic reproduction. This was the case in Conasauga.

According to Suárez-Orozco's (1998) theory, when their script is dismissed, those articulating anti-immigrant views feel even more disempowered, more anxious, and as a result even more anti-immigrant. Thus, the self-defeating likelihood of their articulating the anti-immigrant script in an unacceptable fashion only increases. Plaut (1983) notes a long-standing dynamic in Appalachia where communitarian voices of marginal locals are first ignored and then, as the expressions of disenchantment take on less and less appropriate forms, the marginals' hostility increasingly becomes a rationale for others to exclude them.

To the powerful who embrace the pro-immigration script, the increased shrillness of the anti-immigrant xenophobes further rationalizes dismissing them. It also creates an opening in the pro-immigrant script for immigrants to be characterized in comparative and favorable terms in relation to the xenophobes and/or members of historically marginalized groups, i.e., low-income, anxious whites and blacks. This violates an important tenet of self-identity for low-income whites-the sense of white privilege - and perpetuates the deflection of working-class Anglo (and to a lesser extent African-American) rage towards immigrants instead of at the community's power brokers. Anger is directed at the newcomers who allegedly have usurped the perceived status of low-income whites rather than at the advantaged whites who purvey their vision of a stratified social order. The stratified social order is reproduced with the complicity of many who are disadvantaged by it.

Gibson's (1996) study of a low-income white community in northern Florida parallels in many ways the history and pre-Hispanic-migration demography of northwest Georgia. She noted the importance of the construction of racist attitudes for poor whites' sense of identity and community and claimed that, through the dismissible articulation of racist viewpoints (dismissible and offensive according to white-collar whites), low-income whites co-construct their own marginality, thereby also perpetuating the advantage of the powerful. Although it is both nostalgic and 
phantasmagoric, the one "privilege" that low-income whites have is their whiteness. Thus, Conasauga's emergent pro-immigration script that constructed working class whites as lower status than Hispanic newcomers could be centrally threatening to working class whites and further compel them to articulate the anti-immigration script.

The low-income whites Gibson studied in rural Florida were bound by a contradiction between their social identification with other whites (and thus with white privilege) and the reality of the little power and control they had over their lives. She summarized their dilemma as, "Representations of whites as singularly successful thus serves the interests of the privileged group because it hides the real social and economic disparity between privileged and poor whites and so obstructs identification with similarly-situated minority members" (1996:387). That most poor white Conasauga and Dameron County residents did not identify with similarly situated Hispanics or blacks can be shown through the pariah status accorded to low-income white women who had married Mexican men (Kelley 1996).

Gibson brings up relative deprivation, in which happiness or disaffection with the social order is not a direct product of having more or having less, but rather of having more or less than one expects to have, particularly in relation to various referent groups (Aberle 1962). If one has internalized the idea that one's group identity (e.g., as a white person) is supposed to include privilege, then falling short of the fully subjective concept of privilege means feeling relatively deprived and thus unhappy. If, according to an internalized sense of racial or ethnic hierarchy that is reiterated by ethnic segmentation at the work place, one's alleged privilege is blatantly jeopardized by the intentional advantaging of another group (e.g., through affirmative action or an effort like the Binational Partnership), resistance to the advantaging effort is expectable. Class related xenophobia is a logical result.

Such class-related xenophobia by articulators of the anti-immigration script could be viewed as an attempt to assert co-equal community membership with the more advantaged, but through its failure it served the class interests of the advantaged and the espousers of the pro-immigration script. In the meantime, the play of both scripts produced a local political climate that to the newcomers could appear on the one-hand frightening (the anti-immigrant script) and on the other falsely seductive 
(the pro-immigrant script). It was falsely seductive because espousers of the pro-immigration script did not necessarily have the interests of immigrants foremost in mind. Those designing the Binational Partnership and those championing the pro-immigration script were not the allies that they at first appeared to be.

\section{The Play of Scripts: The Case Study}

Since becoming a local trading center after the Civil War, Conasauga's intra-community social relations have been complicated, interdependent, and stratified. Recent inter-ethnic relations and host-community understandings of the newcomers have been built on the existing story lines regarding individual and group prerogative, place, identity, and role. One constant theme for the last century has been the inverse relation between increased community wealth (not necessarily evenly distributed) and a decline in familial autonomy for most households (as families individually controlled less and less of the production required to keep their households viable). Thus, increased prosperity has coincided with an increased sense of dislocation, lack of control, and anxiety.

Given the disaggregative forces of market capitalism-management wants to maximize the profit it can realize per employee, while employees want profits to be reduced in favor of higher wages-Conasauga, like many communities, has needed to invent communitarian forces and ideologies that could counter or deny social fracture. This section examines both the divisive forces and ideologies in Conasauga and the countering efforts that were relevant to the reception of incoming Hispanics in the 1990s and to the opportunity horizon they encountered locally. These dynamics also relate to the varying receptions encountered by the Binational Partnership and even help explain that Partnership's original creation. One can interpret the creation of the Binational Partnership as an effort to stave off community fracture.

Despite Conasauga's century-long economic emergence (Flamming 1992), its African-Americans were historically excluded from most of the community's economic success, first through "legal" segregation and subsequently by inadequate amends, e.g., 7.0\% of white households and $0.7 \%$ of black households had annual incomes over $\$ 75,000$ in Dameron County (The Daily Citizen-News 1995). But because the local Afri- 
can American population historically has been small and proportionally declining ${ }^{13}$ for the bulk of the century, poor whites have also been materially marginalized and publicly characterized as problematic in the discourse rationalizing the prevailing unequal capitalist order.

Much like the subjects in Gibson's Florida study (1996), in Conasauga and surrounding North Georgia environs there was an identifiable population of low-income whites with limited school experience and success and frequently with comparatively high usage rates of welfare and other government aid programs. ${ }^{14}$ This population, which would be designated either "Appalachian" or "Southern" by those engaged in regional studies, was sometimes overtly stigmatized with labels like "red neck" and "poor white trash." But even when not so labeled, local white collar professionals often still negatively contrasted this population with the growing Hispanic immigrant population. ${ }^{15}$

According to one of my school district informants, Conasauga's influx of Hispanics in the 1990s was displacing low-income whites and blacks from Conasauga's East Side, where the bulk of the city's lower cost housing was located. According to the same informant, Hispanics were gaining a reputation among local landlords for being more prompt with rent payments and better at keeping up properties than other types of tenants. I subsequently found a local landlord who confirmed this sentiment. However, the school district official's perspective is important because it highlights that the perception in Conasauga that Hispanics were dislocating low-income whites and blacks was not restricted to those who were involved with real estate and rental property.

The dynamic described by the school district informant and the landlord depicts physical ramifications of the pro-immigration script. Like Houston (Hagan and Rodriguez 1992) and Chicago (Conquergood 1992), Conasauga's real estate industry was a mediating institution (Lamphere 1992). It helped structure the local social order along ethnic/racial lines, and it helped shape the related ideational lenses through which members of different ethnic/racial groups viewed one another. In Conasauga, the real estate industry was conferring higher status to Hispanic newcomers than to long-time low-income white and African American residents.

Echoing the landlords, other leading Anglo voices in Conasauga also cast local Hispanics in preferable terms in comparison to portions of the more established population. Repeating Suárez-Orozco's (1998) impos- 
sibly virtuous pro-immigration script, a December 1996 editorial in The [Conasauga] Daily Citizen-News (1996:4A) that endorsed the proposed Binational Partnership, claimed that "For too long [Conasauga] and [Dameron] County have walked by the growing Hispanic community, rarely offering substantial help." They seemed unaware that they had differentiated this Hispanic, "not us," newcomer population from the named city and county population. The editorial writers then characterized local Hispanics as "hardworking," "filling some of the toughest manual labor jobs around," and "an example of intensive familial ties."16 Having praised local Hispanics, the editorial writers thus exempted themselves from the following charge, also in the editorial: "Meanwhile [Hispanics] have been virtually ignored - even hated by some-simply because of their presence."

If Hispanics were the primary group referred to in the editorial, there was also a shadow referent, i.e., the unnamed group(s) that were allegedly not hardworking, not willing to take on the tough manual labor jobs available, and not exemplars of intensive familial loyalty. If local Hispanics were meritorious because of their family and work habits, as per the pro-immigration script, those without those virtues were not deserving of support or sympathy. The closest the editorial came to mentioning the shadow referent was with the vague pronoun "some" in the phrase "even hated by some."

A brief retelling of local history, particularly as it involves the local newspaper, clarifies to whom "some" referred. In 1995, before the Binational Partnership had been suggested by anyone, several citizens began a slow stream of letters-to-the-editor questioning and complaining about Conasauga's changing demographic face. The author of one early letter sarcastically wrote:

Am I to understand that people in our community are upset [Conasauga] has become a haven for uninvited guests? .. Just because the crime rate in [Conasauga] has risen considerably in the past couple of years. Just because the local law enforcement is overburdened by a whole new (to them) criminal subculture. Just because native [Conasaugans] prefer to retain their own language- poor English or not-is no reason to be uncivil to guests. 
Several components of this letter merit highlighting: Hispanics were labeled as a criminal subculture; Hispanics were characterized as guests; and Hispanics were labeled as uninvited, hinting at a distinction among long-time Conasaugans between those who "invited" Hispanics (by employing them) and those who did not. With a leap of logic, the author implied that the presence of Hispanics had imperiled the retention of English by English-speakers. Finally, the author made claims about her own socioeconomic status and group membership with the self-denigrating reference to "poor English." Though, as the letter itself shows, the author's English was generally fine, she distinguished herself from the presumably more educated, better speakers of English who perhaps were not threatened by the Hispanic influx. Her loyalty was with native-born, "law-abiding" Conasaugans, who might not be so accomplished in terms of schooling, but who nonetheless had the right to express their concern about how Conasauga was changing.

In contrast, in 1998, a carpet industry executive mentioned to me the same rise in Dameron County's crime rate that was referred to by the anti-immigrant letter writer. But he rationalized the increased crime rate (or increased arrest rate) as related to Hispanics being disproportionately cited for DUIs which, he went on to explain, was the simple product of newcomer Hispanics simply lacking awareness of local rules regarding alcohol use. The same executive also claimed that, because of Hispanics' relative poverty, they lacked sufficient private space in which to be festive without running afoul of the law. Neither the defender of "poor English" nor the carpet executive suggested that the changing arrest rate could also be a product of an entirely non-Hispanic police force targeting the newcomers for closer scrutiny or some other host community reaction, which to me also seemed to be plausible explanations.

By the autumn of 1995, a year before the Binational Partnership was first proposed, the trickle of anti-immigrant letters-to-the-editor had become a torrent. Claims like that in a May letter that "We're losing control of our borders" became increasingly common. In October, shortly after an INS raid at a local carpet mill had led to the arrest of several hundred undocumented workers (Rehyansky 1995a, 1995b), the letters became especially virulent. The Daily Citizen News responded by declaring a temporary moratorium on anti-immigrant, anti-Hispanic, lettersto-the editor. Though the local paper has long been identified with ad- 
vocating local business leaders' points of view (Kelley 1996) and for not supporting more nativist or reactionary perspectives, the letter-to-the-editor moratorium blocked access to one of the few public forums through which populist doubt about immigration could be expressed. Was a major portion of the local population dubious about accommodations to Hispanic newcomers? Yes. Were they welcome to express these doubts publicly? No.

The point here is not to defend a racist discourse, which is what the letters-to-the-editor often were. Rather, what needs highlighting are the divergent responses that actions like the newspaper's moratorium and the INS raids precipitated. As noted above, the less educated, predominantly-white working class had serious doubts about how immigration was changing their community, but these residents' resistant voices were formally silenced. ${ }^{17}$ In the meantime, many of the civic-minded elite were concerned about the increasingly obvious fracture in their community and the social ferment that risked being directed at their businesses. Repairing the social fabric and thus, indirectly, reiterating the rationale for a social order that benefited them were the implicit priorities of the civic-minded elite. Repressing the anti-immigration script was an incomplete gesture. They needed proactively to demonstrate their responsiveness to immigration-related community concerns. They did this dramatically with the Binational Partnership as well as in less grandiose ways like the 1997 radio station controversy discussed below.

A September 1997 controversy about a planned change in a local AM radio station's format (Jackson 1997a, 1997b) serves as an example of 1ocal residents' sense of dislocation, the pro-immigration and anti-immigration scripts, and one more on-the-ground display of an indirect social cost (at least from the perspective of some) generated by local companies' hiring practices. Local citizens became upset by a proposed conversion to a Spanish-language/Mexican music format at Conasauga's oldest radio station. The change was proposed because of a steady decline in listeners to the existing adult contemporary music format. A burst of public outcry ensued.

While the 1997 radio station issue was of lesser degree than the 1995 letter-to-the-editor moratorium controversy, many themes were similar. One woman wrote: "Well, well, the Hispanics have taken over a number of things here and now they get [our] radio station. That is the first 
station we ever had, and if they need a radio station, why can't they get a new one and leave our historic radio station alone?" Her letter and several others of the same ilk failed to note that the format change was not proposed by Hispanics but by Anglos who sensed that the format change would bring more advertising money than the tired, existing format was generating. Meanwhile, other letters dismissed the angry letter writers as racist and regressive. Thus, the temporary controversy became a new forum for Anglo meaning-making regarding ethnicity, community, and inclusion/exclusion. Long lasting community fracture lines were reiterated and not healed when the radio station's owner decided to switch another of its AM stations to a Spanish-language format. The historic station was switched to a still-in-English talk-radio format, which apparently was not viewed as a cause for irate reaction.

\section{Locating the Binational Partnership in the Public Sphere}

What does reviewing the economic and cultural dynamics extant in Conasauga have to do with the Binational Partnership? First, it contextualizes the debate that surrounded the Binational Partnership and suggests a rationale for those acting both for and against the Partnership. Second, it helps show how those both for and against the Partnership were prone to simplifying and misrepresenting the Partnership's action plan and the intent of many of its designers. After all, they had simplified and misunderstood other processes and actions tied to the local demographic changes. In the public discourse, neither the anti-immigration nor the proimmigration scripts provided a rationale for community transformation, for the ready acceptance of immigrants as they were, or for the rearticulation of school goals to prepare transnational students to negotiate the multiple social and economic environments that they might encounter as children and later as adults. The Partnership's original compact promised such changes, but the pro-immigration script, the anti-immigration script, and their shared de facto silencing of Hispanic newcomer voices together created a simplified ideological landscape in which the transformative prospect of the Binational Partnership was at least partially emasculated.

Rather than waiting for the January 1997 arrival of the Mexican researchers who were to co-create the Binational Partnership, the local newspaper published several articles favorably describing the promise of 
the still prospective Binational Partnership in December 1996 (e.g., Hamilton 1996a, 1996b). I am not sure whether these articles were the result of a coordinated campaign by the Binational Partnership's powerful initiators, though that seems probable. I am, however, sure that the articles were intended to lay a favorable foundation for popular acceptance of the Binational Partnership which was promoted by the business elite whose perspective was echoed in the local newspaper. At the same time the articles were being published, the attorney instigating the Binational Partnership was busily sending descriptions of the Partnership and bids for its support to several of the state's most powerful political and educational leaders. Both the articles and the attorney's letters contrasted markedly with the anti-immigration sentiment noted in the last section, but they, too, conveyed a simplified, overly homogenizing, rendering of the growing local Hispanic population and, in particular, of the Hispanic newcomer students who were to be main targets of the Binational Partnership's programs. The rendering was expedient for the purpose of gathering Anglo community support for the Partnership, less so for actually conveying a sense of what the Partnership needed to accomplish.

The first newspaper article (Hamilton 1996a) was published the day a Conasauga Public Schools team left for its first visit to Mexico and first face-to-face contact with the prospective Mexican partners. The article began with the question, "How do you teach someone you cannot communicate with?" and the answer: "You can't." Titled "Educators seek ways to reach Hispanics," the article identified the problem of Hispanics in Conasauga schools as a communication problem and presented the Binational Partnership as a solution to the problem. The article described the Partnership one-dimensionally (referring only to the prospect of bilingual Mexican teachers coming to Conasauga), and published for the first time the "creation story" (and rationale) for why the Partnership was being instigated.

The Binational Partnership's (Hamilton 1996a) went as follows: One day the monolingual daughter of the Partnership's founding attorney had exasperatedly described to her father how difficult her and her colleagues' task was. At the time, the attorney's daughter was serving as a "parapro" (paraprofessional) at a pre-Kindergarten through grade 2 elementary school on the poorer and more Hispanic side of town. She and her colleagues were all monolingual English speakers while many of their 
students and their students' parents were monolingual Spanish-speakers. According to the daughter, the two sides could not communicate. Feeling compelled to try to remedy this mismatch, but not immediately sure how to proceed, the attorney visited the school where his daughter worked. Disconcerted by what he found, he mentioned his daughter's complaint to the CEO of one of Conasauga's largest carpet manufacturers. ${ }^{18}$ The CEO in turn contacted the head of one of his company's Mexican trading partners. That Mexican contact, who was also a lead supporter of a private Mexican university, telephoned the Rector of that university. Soon a parapro's complaint was transformed into a discussion about how a Mexican university might be able to help the public schools in Conasauga to overcome their communication gap.

This "creation story" of the Binational Partnership was repeated frequently and was central to selling it to local Anglos, including to those who were skeptical. The creation story was readily intelligible to its target audience and effective in gaining their support. However, the story simplified the challenge confronted by school and community and, in the security of its problem diagnosis, it precluded any need to consult with any of Conasauga's Hispanic newcomers. During the planning for the first year of the Partnership's enactment, only one local Hispanic was even intermittently involved with the Partnership's coordination; apart from this limited exception, the Partnership was fully the product of local Anglo business leaders, Anglo school district leaders, and Mexican university officials.

The second December 1996 newspaper article (Hamilton 1996b) promoting the proposed Partnership was also a front-page piece. It was printed shortly after the Conasauga contingent returned from their visit to the Mexican university and was crucially different from the first. The second article outlined four proposed components for the Binational Partnership, instead of just the recruitment of Mexican teachers for Conasauga schools originally sought. At the request of the Mexican scholars in the Partnership, summer training in Mexico for Conasauga educators, a bilingual education-oriented curriculum overhaul, and a community research component were added to the Partnership's proposed action plan. The Mexican scholars remember agreeing to join the Partnership only after these proposed additions were accepted. Despite the increase in the number of proposed components for the Partnership, the second article 
did not change its straightforward depiction of Conasauga's challenge as the remedy for communication gaps between newcomers and teachers at the public schools.

Within a week, there was a third article (The Daily Citizen-News 1996), an editorial celebrating as "Citizen of the Week" the attorney who initiated the Binational Partnership and who led the contingent of Conasauga business leaders to be involved with it. Perhaps seeking a metaphor that would be broadly appealing in a town as religious as Conasauga, the article compared the attorney to the Good Samaritan described by Jesus in the New Testament. The attorney was lending a helping hand while other Conasaugans remained silent. The moral of the Bible story is that those who lend a helping hand are blessed and holy, while the silentthose who do not offer a helping hand-are not so virtuous. It is worth remembering that the man helped by the Samaritan in the Bible had been robbed and beaten and was a stranger to the Samaritan. According to analogy in the editorial, Hispanics in Conasauga were abused, suffering, needy strangers.

The day after Christmas 1996, the attorney penned a letter describing the proposed Binational Partnership to the newly appointed Chairman of the State Board of Education. This letter emphasized how the attorney and the new chairman were personally connected, i.e., college fraternity ties, shared friends and acquaintances. It conveyed the attorney's enthusiasm for the nascent Partnership and suggested the need by accounting statistically for Conasauga's changing demography. However, it did not mention the Partnership's proposed four component structure nor their rationales. Rather, the Partnership was again reduced to a program to remedy the communication gap by recruiting Mexican instructors to come to Conasauga classrooms.

The daily newspaper printed another flurry of favorable articles at the end of January 1997 during the four day visit of the Mexican university representatives. Headlines for those articles include: "Communication revolution arrives in Conasauga today" (Hamilton 1997a), "Visiting professors shocked by size of communication problem" (Hamilton 1997b), and "Business involvement aids binational partnership" (The Daily Citizen News 1997a). Reiterating that Hispanic students and Anglo teachers in Conasauga faced a communication gap and that the Binational Partner- 
ship would bridge that gap thus solving Hispanic students' problems, the "Visiting Professors Shocked" story began with a description of a lengthy conversation (presumably in Spanish) between one of the Mexican visitors and a young Hispanic student. The student's local teacher expressed shock at the exchange because she had never seen the girl particularly expressive. According to the article, the teacher had previously worried that the girl had a speech or learning problem. The article's intended conclusions were easy to draw. If only somebody could communicate with these Spanish speaking students, the students' general talent could be displayed and cultivated.

These articles did not note such obstacles to Hispanic students' achievement as related to their parents' economic vulnerability, their families' uncertain ties to Conasauga, their possible learned skepticism towards schools, and/or their transience. Nor did the articles critically consider how the macro-dynamics of businesses' externalization of indirect costs, the segmentation of labor markets, the ethnic typing of jobs, and the national and local constructions of Hispanic newcomers in the media might also have been impediments to Conasauga Hispanic students' achievement. ${ }^{19}$ Absent a public discourse describing the multiple and often intertwined factors that can inhibit Hispanic newcomers' school success, the intentional complexity of the Binational Partnership's four component design lacked public support.

In the articles, the permanent presence of Conasauga's Hispanic community was emphasized as a rationale for action. Local businesses were celebrated as the instigators of the solution to problems implicitly associated with the influx of newcomers, rather than seen as sources of the problem or as merely meeting their responsibilities. The changes of habit and accommodations required of both the schools and the larger community were not explained in much detail in the articles. Unvoiced, they remained vague and compelled little consideration.

Still, the Partnership was officially inaugurated in March 1997 as a four component effort. Major funding ostensibly to support all four components was obtained a month later, although as described in the final section, the Conasauga school district's willingness to spend funds and to develop programs in each of the areas for which funding had been obtained later proved problematic. 


\section{Two Years Later-A Provisional Conclusion}

Fast forwarding two years to the spring of 1999, the Binational Partnership was a significant and sometimes celebrated local presence that had gained national attention from the Washington Post, Time, the San Jose (CA) Mercury-News, Scripps-Howard News Service, National Public Radio, and more. The Director of the U.S. Department of Education's Office for Bilingual Education and Minority Language Affairs (OBEMLA) had spoken at length and favorably about Conasauga in her congressional address supporting the reauthorization of Title VII funding. Yet the Binational Partnership risked disappearing, with most of its accomplishments more ephemeral than transformative. With the exception of a selfsustaining Hispanic community leadership initiative, most portions of the three components initiated at the request of the Mexican researchers, i.e., the bilingual curriculum adjustment, the summer institute in Mexico, and the community research initiative, were frozen or withering. Only the component originally proposed by Conasauga leaders - the effort to bring Mexican instructors into Conasauga classrooms - was thriving, and even it was vulnerable to the pending end of various funding allocations. Figuring out why so much of the Partnership's promise was not yet realized and in jeopardy requires looking back at two crucial 1997 Partnership-related events and the persistent power of Anglo conceptualizations of local Hispanic roles, needs, and entitlements.

In March 1997, at a ceremony at Conasauga High School, the Binational Partnership was formally inaugurated (Hamilton 1997c). The ceremony was attended by several Conasauga carpet executives, the Partnership's initiating attorney, Conasauga and Dameron school district officials, the Rector of the Mexican university, the Mexican industrialist who had facilitated the binational link, the Mexican Consul General from Atlanta, and several scholars from the Mexican university. However, the high school auditorium was largely empty. No students, no parents (Hispanic or otherwise), no high school administrators, and no teachers were present. The start of the Partnership was not cause to interrupt anyone's school day. The three-page accord signed that day outlined all four proposed components; it alluded to ideals like "globally competitive education for all learners" and "adult biliteracy," and it promised involvement not just of educators, but also workplaces, parents, and the University of 
Georgia System. Few heard this comprehensive vision, however, and still fewer were willing to adhere to it.

A month later, two challenges to the nascent Partnership were presented at the city council meeting at which a $\$ 750,000$ allocation for the Partnership was ultimately approved. The first challenge was the angry chorus of protesters assembled outside city hall. One of the protesters held a sign that read "Would the last person out of [Dameron] County please bring the flag." Given Dameron County's fast growing population, the sign's argument was as absurd as it was angry. Those inside the meeting ignored the protesters. Later the newspaper dismissed the protesters as offensive racists (The Daily Citizen-News 1997b).

The second challenge superficially seemed less serious than the dismissed first one, but it compelled a public redefinition of the Partnership in such narrow terms that, in retrospect, its influence demands recognition. The second challenge was the circulation of a Readers Digest article by Linda Chavez ${ }^{20}$ (1995) to a city councilman (and subsequently to the whole City Council). ${ }^{21}$

The article included a virulent attack against bilingual education and all who advocate for it. The article further asserted that Hispanics needed to be taught English, positing the flawed argument that those promoting bilingual education did not want Hispanics to learn English and reducing the broad academic goals of bilingual education to a simplified concern with language acquisition rather than academic achievement in all subject areas. Because the Binational Partnership included rhetoric supporting bilingual education, the article encompassed a criticism of at least a portion of the Partnership.

The attorney dismissed Chavez' argument in a reply to the councilman. He compared its validity to the pseudo-science claims that blacks are less intelligent than whites. Nonetheless, he and other local leaders of the Partnership responded to the "Chavez challenge" by clarifying that the Partnership's primary intent was to teach Hispanic children English, a story line that was dutifully echoed in an editorial in the local newspaper (The Daily Citizen-News 1997b). As soon as this argument was put forth, the rationales for enacting all portions of the Partnership that could not be directly related to this language education task were diminished.

To understand how such a redefinition of task could occur (and how the redefinition was not recognized as a redefinition) requires re- 
turning attention to Conasauga Anglos' understanding of Hispanics and their needs. With the exception of the Partnership's instigating attorney who, at times, articulated a nuanced understanding of the complexity of Hispanic community circumstances in Conasauga-e.g., his "Conasauga is a border city" toast-local proponents of the Binational Partnership saw the challenges before them through the lens of SuárezOrozco's (1998) pro-immigration script. The simplistic vision of assimilation embedded in this script supported the original rationale for the Partnership-Hispanic newcomers were deserving people and as such deserved to be able to be communicated with. In the short term, bringing in bilingual educators from Mexico would remedy this communication problem; in the long-term, assimilation would prevail. This simplistic vision prevented its adherents from identifying any problem with a language-education-only program; it could not conceive of Hispanics resisting such a program. This vision did not address, for example, the arguments of Ogbu (1987) regarding how Latino immigrant students sometimes take on the resistant persona of caste-like minorities as they determine that U.S. society offers them an unfairly restricted opportunity horizon. Nor did adherents of the pro-immigration script see that the obstacles confronted by Hispanic newcomers were more complex than just those associated with language skills, e.g., Singh, Lele, and Martahardjono's (1988) argument that inequities in power reduce the tolerance/patience of the more powerful towards the less powerful in communicative interaction. The adherents further ignored persistent demands of the capitalist order for segmented labor markets (Griffith 1995) and other ways of holding down costs by restricting aspiration and opportunity. Thus, the pro-immigration script did not require tending to the complicated circumstances and needs of Hispanic newcomers, nor did it compel its adherents to defend the full action plan of the Binational Partnership.

Returning to Lamphere's (1992) and Goode, et al.'s (1992) recognition of schools as important mediating institutions that transfer the scripts, patterns, and codes of the larger society to an individual, it should not be surprising that the public discourse regarding Conasauga's newcomer Hispanic population steered the praxis of the Binational Partnership along hegemonic lines. In more accessible language, with the prospects and purposes of the Binational Partnership simultaneously simplified 
and murky, it should not be surprising that Anglos' prevailing notions of Hispanics and of the task at hand carried the day.

Sarason (1990) noted that transformative school reform efforts require both inclusion of the larger community and attention to issues of power. At first glance, the Binational Partnership tended to both of those dynamics, involving the business community and using its power to push for school change. However, the exercise of the business community's power did not provide a sufficiently coherent and sophisticated problem diagnosis, i.e., it did not clarify what accommodations local Hispanics most needed, nor did it clarify how non-Hispanics could be enabled to re-envision the roles of the schools and the definition of community. In the absence of a local, Anglo-recognized script that supported the Partnership's comprehensive vision, the prevailing simplistic pro-immigration and anti-immigration scripts had free play in the community. Their challenges of each other excluded a call for representation of Hispanic voices and obscured the embedded simplifications in each script.

McQuillan (1998) has noted that culture is routinely contested, but he also notes that it is resilient, equivalent to a kind of default setting for expectations. Culture puts parameters on what seems possible, supporting hierarchies agreed upon by group members as to what seems normal and appropriate. In the absence of a clear framework to act otherwise, most of the individuals in Conasauga leading the Binational Partnership were limited in imagining the Partnership's transformative potential, even though on paper they had accepted a transformative plan.

Broader Anglo constructions of the roles and place of Hispanic newcomers remained similarly limited, as frustration with the externalization of businesses' indirect costs became frustration with Hispanic newcomers rather than with businesses. The rationales tied to segmented labor markets remained salient and compelling to native workers; the dismissal of host community responsibilities to sojourner laborers continued; and allegiance to the nostalgic vision of idyllic assimilation embodied in the proimmigration script remained unproblematized in the face of the struggles to create and sustain the Binational Partnership. Anglo conceptualizations of the Hispanic newcomer other restricted the realization of the Binational Partnership's promise, revealed limited understanding of the complexity of Hispanic newcomers' circumstances and aspirations, and 
endorsed the continued reproduction of a more demographically complex but still stratified social order.

While Conasauga is not anywhere-it was a particular community, with a particular history, and a particular response to demographic transformation - the tale of its circumstances and its Binational Partnership needs to be heard elsewhere. Other U.S. communities in such disparate places as Maine (Wortham 1997), North Carolina (Villenas 1997), and Kansas (Grey 1991) are also newly negotiating the presence of Hispanic newcomers and being powerfully shaped by how the host community views the newcomers. Beyond the issues of Hispanic demographics and immigration into the United States, it is my hope that this case study follows Lamphere's (1992) lead and highlights the value of considering how macro-dynamics are mediated to be salient at the local and individual level. The macro-to-micro perspective can be fruitfully reversed, however. This paper can be read as an account of how small deeds, e.g., letters-to-the-editor, habits of specific landlords, stories told to rationalize the creation of a binational partnership, create the macro-dynamics of segmented labor markets, sojourner laborers and families who struggle to imagine themselves as part of the community in which they work, and dislocation. These macro-dynamics were in play across the United States and well beyond.

Finally, I should end as I began with two caveats. The changed demography of Conasauga meant that Anglos and Hispanics were working sideby-side, shopping at the same stores, and ultimately getting to know each other. The simplified popular Anglo imagining of Hispanics displayed here could not help but become more complicated. Also, away from concerned or prying Anglo eyes, Mexican university officials had used the Partnership as a means to initiate an Hispanic leadership council which quickly became self-sustaining. That council's political organizing and its articulations of what kind of community it wanted to build, of how Hispanics hoped to contribute to that community, and of what they expected to derive from it all left open the prospect that hegemonic reproduction might yet be interrupted, that a vision more complicated than the dichotomous but partnered pro-immigration and anti-immigration scripts could emerge. 


\section{Notes}

An earlier draft of this paper was presented at the 97th annual meeting of the American Anthropological Association in Philadelphia, PA in December 1998 in a session entitled "Spanish-Speaking Populations in the Anthropological Imagination." The Binational Partnership was the topic of my dissertation (Hamann 1999).

1. I am using Todorov's (1984) definition of other to designate those who are not $u s$.

2. The city and county names are fictional.

3. Technically, Dameron County Schools were also part of the Binational Partnership, but their role was so limited during my study period of March 1997 to November 1998, that they are largely omitted in this paper. The only school officials involved in the Binational Partnership's design were from the Conasauga City district.

4. I am using Park and Burgess's (1970 [1921]:360) classic definition of accommodation: "The process of adjustment, that is, an organization of social relations and attitudes to prevent or to reduce conflict, to control competition, and to maintain a basis of security in the social order for persons and groups of divergent interests and types to carry on together their varied life-activities."

5. This funding included a $\$ 500,000$ five-year Title VII Systemwide Bilingual Education grant. My entree into Conasauga was through a contract with the public schools to write this successful grant proposal.

6. The pro- and anti-immigration scripts used throughout the paper are from Suárez-Orozco (1998).

7. The term "American" here follows standard U.S. usage, i.e., to designate residents of the country, not the hemisphere.

8. Most simply, a segmented labor market refers to a labor pool that is hierarchically stratified, e.g., between white collar and blue collar, within blue collar categories and so on. Within an industry and even a specific company there are quite often multiple gradations of salary, variations in job safety and security, and informal gradations in job status. Such stratifications usually have psychological and cultural dimensions, which compel workers to protect the relative status and benefits of their position rather than to question the general social organization of the workplace. Two dimensions of labor market segmentation matter most here: the ethnic marking of certain job-types (see the discussion of Tienda's [1989] ideas in the main text) and the way the segmentation interferes with the creation of solidarity between groups of workers. In Conasauga, one popular rationale for welcoming Mexican newcomers is the newcomers' willingness to work jobs that no one else wants, i.e., jobs that are 
dangerous, low-status, relatively low-wage, or otherwise less desirable. Improving the conditions of these jobs, however, so that they were better compensated than some job categories occupied mostly by Anglos, or facilitating the career advancement of Mexican newcomers into higher status job categories would, according to the implications of segmented labor market theory, be threatening and unwelcome from various Anglo perspectives.

9. Push factors dislocating immigrant newcomers from their Mexican communities were also important reasons that a mediating institution dynamic emerged in Conasauga, but because those dynamics occurred generally beyond the ken of Anglos in Conasauga, their impact on Anglo conceptualizations of Hispanics was relatively small. Thus, push factors are not examined in this paper. See Massey, et al. (1987) and Portes and Bach (1985) for discussions of many of the push factors extant in Mexican sending communities.

10. Sarason (1990) has hinted that similar dynamics are common among school district employees and in other complex organizations.

11. Some sojourner laborers do use their U.S. work experience to accumulate enough capital that a full-time return to Mexico is possible. In these instances the label "temporary" may be superior to "sojourner." Other originally sojourner workers manage to stay in place long enough to establish local ties and become permanent settlers. Many sojourner laborers, however, endure a kind of geographic limbo over long stretches of time.

12. Grey (1991:80) summarizes my use of "assimilation" here: "Assimilation ... is a one-way process in which the outsider is expected to change in order to become part of the dominant culture."

13. Conasauga's experience matches the long-term black emigration from all over the Appalachian core region noted by Williams (1996).

14. The National Adult Literacy Survey (Portland State University 1996) which relied on 1990 Census data found that $40 \%$ of Conasauga's adult population had not completed high school, with almost half of those not having completing ninth grade.

15. See Banker (1996), Plaut (1983), and Puckett (1989) for more on how low-income Appalachian whites have been marginalized by the local middleclass and elite, as well as by middle-class and elite outsiders.

16. Sofia Villenas (personal communication) found similar characterizations of Hispanics as familial, hardworking, and loyal in her North Carolina research site.

17. As previously noted, Plaut (1983) described how marginal Appalachians' decisions to resist change using formats unacceptable those with more power, e.g., violence, hostile nativism, facilitated the dismissal of these marginals' complaints without redress. 
18. The attorney also approached the school district and was shocked to find no coherent plan to respond to the challenges presented by Conasauga's influx of Hispanic newcomers. This portion of the story, however, was not usually repeated as part of the "creation story."

19. There is a large and growing body of literature on Hispanic schooling, see, for example, Dentler and Hefner (1997), Erickson (1987), Meier and Stewart (1991), Miramontes, Nadeau, and (1997), and Valdes (1996).

20. Linda Chavez is an outspoken, right-wing critic of bilingual education who is largely dismissed by mainstream educational researchers.

21. While this article does not review bilingual education research, readers should note that Linda Chavez's claims are sharply contradicted by vast amounts of research, including Thomas and Collier (1997), Cummins (1996), and Ramirez (cited in Cazden [1992]).

\section{References Cited}

Aberle, David

1962 Millennia1 Dreams in Action. In Comparative Studies in Society and History, Supplement 11. Sylvia L. Thrupp, ed. Pp. 209214. The Hague: Mouton \& Co.

Banker, Mark

1996 Unraveling the Multicultural Riddle: Clues from Southern Appalachia and Hispanic New Mexico. Journal of Appalachian Studies. 2(2):277-298.

Cazden, Courtney B.

1992 Language Minority Education in the United States: Implications of the Ramirez Report. National Center for Research on Cultural Diversity and Second Language Learning. http://www. ncbe.gwu.edu/miscpubs/ncrcds11/epr3/index.html

Chavez, Leo R.

1994 The Power of the Imagined Community: The Settlement of Undocumented Mexicans and Central Americans in the United States. American Anthropologist. 96(1):52-73. 
Chavez, Linda

1995 One Nation, One Common Language. Readers Digest (Aug.):87-91.

Conquergood, Dwight

1992 Life in Big Red: Struggles and Accommodations in a Chicago Polyethnic Tenement. In Structuring Diversity: Ethnographic Perspectives on the New Immigration. Louise Lamphere, ed. Pp. 95-144. Chicago: University of Chicago Press.

Cummins, Jim

1996 Negotiating Identities: Education for Empowerment in a Diverse Society. Ontario, CA: California Association for Bilingual Education.

Daily Citizen-News, The

1995 Lifestyle: Times Change. The Daily Citizen-News. 32(Jan. 15):5A.

1996 [The attorney] Leads Effort to Help Educate Hispanic Students. The Daily Citizen-News. 34(Dec. 21):4A

1997a Business Involvement Aids Binational Partnership. The Daily Citizen-News. 34(Jan. 23):4A.

1997b Georgia Project's Aim is to Teach English. The Daily CitizenNews. 35(Apr. 24):4A.

Delgado-Gaitan, Concha

1990 Literacy for Empowerment: The Role of Parents in Children's Education. New York: The Falmer Press.

Dentler, Robert A., and Anne L. Hafner

1997 Hosting Newcomers: Structuring Educational Opportunities for Immigrant Children. New York: Teachers College Press. 
Erickson, Frederick

1987 Transformation and School Success: The Politics and Culture of Educational Achievement. Anthropology and Education Quarterly 18(4):335-356.

Flamming, Douglas

1992 Creating the Modern South: Millhands and Managers in Dalton, Georgia, 1884-1984. Chapel Hill: University of North Carolina Press.

Gaventa, John

1990 From the Mountains to the Maquiladoras. In Communities in Economic Crisis: Appalachia and the South. John Gaventa, Barbara Ellen Smith, and Alex Willingham, eds. Pp. 85-95. Philadelphia: Temple University Press.

Gibson, Jane W.

1996 The Social Construction of Whiteness in Shellcracker Haven, Florida. Human Organization. 55(4):379-389.

Goode, Judith G., Jo Anne Schneider, and Suzanne Blanc

1992 Transcending Boundaries and Closing Ranks: How Schools Shape Inter-relations. In Structuring Diversity: Ethnographic Perspectives on the New Immigration. Louise Lamphere, ed. Pp. 173-2 13. Chicago: University of Chicago Press.

Green, Larry

1996 Influx of Hispanics could change [C]HS athletics. The Daily Citizen-News. 33(May 15): 1B.

Grey, Mark A.

1991 The Context for Marginal Secondary ESL Programs: Contributing Factors and The Need for Further Research. The Journal of Educational Issues of Language Minority Students 9:75-89. 
Griffith, David

1993 Jones's Minimal: Low-Wage Labor in the United States. A1bany: State University of New York Press.

1995 Hay Trabajo: Poultry Processing, Rural Industrialization, and the Latinization of Low-Wage Labor. In Any Way You Cut It: Meat-Processing and Small-town America. Donald D. Stull, Michael J. Broadway, and David Griffith, eds. Pp. 129-151. Lawrence, KS: University Press of Kansas.

Guerra, Juan C.

1998 Close to Home: Oral and Literate Practices in a Transnational Mexicano Community. New York: Teachers College Press.

Hackenberg, Robert A.

1995 Joe Hill Died For Your Sins. In Any Way You Cut It: Meat Processing and Small-town America. Donald D. Stull, Michael J. Broadway, and David Griffith, eds. Pp. 232-264. Lawrence, KS: University Press of Kansas.

Hagan, Jacqueline Maria and Nestor P. Rodriguez

1992 Recent Economic Restructuring and Evolving Intergroup Relations in Houston. In Structuring Diversity: Ethnographic Perspectives on the New Immigration. Louise Lamphere, ed. Pp. 145-171. Chicago: University of Chicago Press.

Hamann, Edmund T.

1999 The Georgia Project: A Binational Attempt to Reinvent a School District in Response to Latino Newcomers. Doctoral dissertation, University of Pennsylvania. Ann Arbor: University Microfilms.

Hamilton, David W.

1996a Educators Seek Ways to Reach Hispanics. The Daily CitizenNews. 34(Dec. 12): 1,6A. 
1996b Trip to Mexico May Lead to Historic Deal. The Daily CitizenNews. 34(Dec. 17): 1,5A.

1997a Communication Revolution Arrives in [Conasauga] Today. The Daily Citizen-News. 34(Jan. 22):

1997b Visiting Professors Shocked by Size of Communication Problem. The Daily Citizen-News. 34(Jan. 25): 1,3A.

1997c [Conasauga] in Historic Pact with Mexican University. The Daily Citizen-News. 34(Mar. 20): 1

Jackson, Robert

1997a WBLJ to retain English format. The Daily Citizen-News. 35(Sept. 17): 1.

1997b Local Radio Station Goes All-Hispanic. The Daily CitizenNews. 35(Oct. 17):1.

Kelley, Kathryn A. (Kitty)

1996 On Their Own: American Working Class Women Married to Mexican Immigrant Men in the Rural South. Masters thesis, Georgia State University.

Lamphere, Louise

1992 Introduction: The Shaping of Diversity. In Structuring Diversity: Ethnographic Perspectives on the New Immigration. Louise Lamphere, ed. Pp. 1-34. Chicago: University of Chicago Press.

Macias, Jose

1996 Resurgence of Ethnic Nationalism in California and Germany: The Impact on Recent Progress in Education. Anthropology and Education Quarterly. 27(2):232-252. 
Massey, Douglas S., Rafael Alarcon, Jorge Durand, and Humberto Gonzelez

1987 Return to Aztlan: The Social Process of International Migration from Western Mexico. Berkeley: University of California Press.

McQuillan, Patrick James

1998 Educational Opportunity in an Urban American High School:

A Cultural Analysis. Albany: State University Press of New York.

Meier, Kenneth J., and Joseph Stewart, Jr.

1991 The Politics of Hispanic Education: Un Paso Pa'lante y Dos Pa'tras. Albany: State University Press of New York.

Mencken, F. Carson

1996 Income and Employment Change in Appalachia During the 19831988 Business Cycle Recovery: Location Differential Effects in North, Central, and Southern Appalachia. Journal of Appalachian Studies. 2(1):77-85.

Miramontes, Ofelia B., Adel Nadeau, and Nancy L. Commins

1997 Restructuring Schools for Linguistic Diversity: Linking Decision Making to Effective Programs. New York: Teachers College Press.

Ogbu, John U.

1987 Variability in Minority School Performance: A Problem in Search of An Explanation. Anthropology and Education Quarterly 18(4):312-334.

Park, Robert E. and Ernest W. Burgess

1970 [unabridged original 1921] Introduction to the Science of Sociology: Including an Index to Basic Sociological Concepts (abridged student edition). Morris Janowitz, abr. Chicago: The University of Chicago Press. 


\section{Plaut, Thomas}

1983 Conflict, Confrontation, and Social Change in the Regional Setting. In Appalachia and America: Autonomy and Regional Dependence. Allen Batteau, ed. Pp. 267-284. Lexington: The University Press of Kentucky.

Portes, Alejandro and Robert L. Bach

1985 Latin Journey: Cuban and Mexican Immigrants in the United States. Berkeley: University of California Press.

Portland State University

1996 Adult Literacy Estimates.

http://www.casas.org/lit/litcode/Search.cfm

Puckett, John L.

1989 Foxfire Reconsidered: A Twenty-Year Experiment in Progressive Education. Urbana: University of Illinois Press.

Rehyansky, Mary

1995a Raid Nets 108 Illegals. The Daily Citizen-News. 33(Sept. 21):1.

1995b Operation Southpaw Comes to an End. The Daily CitizenNews. 33(Sept. 26):1.

Sandel, Michael J.

1996 Democracy's Discontent: America in Search of a Public Philosophy. Cambridge, MA: Harvard University Press.

Sarason, Seymour B.

1990 The Predictable Failure of Educational Reform: Can We Change Course Before It Is Too Late? San Francisco: Jossey Bass Publishers.

Singh, Rajendra, Jayant Lele, and Gita Martohardjono

1988 Communication in a Multilingual Society: Some Missed Opportunities. Language In Society 17:43-59. 
Smith, Michael Peter and Luis Eduardo Guarnizo, eds.

1998 Transnationalism from Below. New Brunswick, NJ: Transaction Publishers.

Spener, David

1988 Transitional Bilingual Education and the Socialization of Immigrants. Harvard Educational Review 58(2): 133-153.

Spindler, George and Louise Spindler

1998 Cultural Politics of the White Ethniclass in the Mid-Nineties. In Ethnic Identity and Power: Cultural Contexts of Political Action in the School and Society. Yali Zou and Enrique T. Trueba, eds. Pp. 27-41. Albany: State University of New York Press.

Suárez-Orozco, Marcelo M.

1998 State Terrors: Immigrants and Refugees in the Post-National Space. In Ethnic Identity and Power: Cultural Contexts of Political Action in School and Society. Yali Zou and Enrique T. Trueba, eds. Pp. 283-3 19. Albany: State University of New York Press.

Thomas, Wayne P. and Virginia Collier

1997 School Effectiveness for Language Minority Students. NCBE Resource Collection Series, 9. Washington: National Clearinghouse for Bilingual Education. http://www.ncbe.gwu.edu

Tienda, Marta

1989 Looking to the 1990s: Mexican Immigration in Sociological Perspective. In Mexican Migration to the United States: Origins, Consequences, and Policy Options. Wayne A. Cornelius and Jorge A. Bustamante, eds. Pp. 109-147. San Diego, CA: Center for U.S./Mexican Studies, University of California.

Tienda, Marta and E. Fielding

1987 Migration, Preferential Work Status, and Employment: Divergent Paths of Hispanic Market Insertion in the United States. IRP Discussion Paper. Madison: University of Wisconsin. 
Todorov, Tzvetan

1984 The Conquest of America: The Question of the Other. Richard Howard, trans. New York: Harper \& Row, Publishers.

Valdes, Guadalupe

1996 Con Respeto: Bridging the Distances Between Culturally Diverse Families and Schools, An Ethnographic Portrait. New York: Teachers College Press.

Van Zenten, Agnés

1997 Schooling Immigrants in France in the 1990s: Success or Failure of the Republican Model of Integration? Anthropology and Education Quarterly. 28(3):351-374.

Villenas, Sofia

1997 Una Buena Educación: Latino Education and Cultural Conflict in North Carolina. Paper presented at the 96th Annual Meeting of the American Anthropological Association, Washington, DC.

Williams, John Alexander

1996 Counting Yesterday's People: Using Aggregate Data to Address the Problem of Appalachian's Boundaries. Journal of Appalachian Studies. 2(1):3-27.

Wortham, Stanton

1997 The Unintended Tracking of Latino Schoolchildren in Rural New England. Paper presented at the 96th Annual Meeting of the American Anthropological Association, Washington, DC. 